\title{
Kajian Sustainabilitas Program Indonesia Sehat dengan Pendekatan Keluarga (PIS-PK)
}

\author{
Shofiyatul Masyiyah, Roesdiyanto*, Dian Mawarni \\ Universitas Negeri Malang, Jl. Semarang No. 5 Malang, Jawa Timur, Indonesia \\ *Penulis korespondensi, Surel: roesdiyanto.fik@um.ac.id
}

Paper received: 23-7-2021; revised: 13-8-2021; accepted: 20-8-2021

\begin{abstract}
The results of the Healthy Indonesia Program with a Family Approach (PIS-PK) have not yet reached 100 percent. Home visits and intervention activities occur in their implementation at the national and regional levels. The follow-up intervention was carried out by 32 percent of the Puskesmas in Indonesia. The implementation of PIS-PK in Malang City also in the 2017-2019 period reached 40 percent of home visits and has not been maximized in follow-up interventions. This study was conducted to determine the occurrence of the PIS-PK program in Malang City. This research is a qualitative descriptive study with a cross-sectional approach. The variables studied in this study were political support and community leaders, communication, and evaluation of the PIS-PK program. Instruments in the form of research guidelines were carried out by collecting data in this study carried out with structured interviews from the person in charge of the PIS-PK program. The data analysis of this research was done by reducing and drawing conclusions from the interviews. Political support and community leaders are carried out at the Puskesmas level with RT, RW, Kelurahan but the city government does not support it optimally. Communications carried out at PISPK are top to down using social media in establishing cross-sectoral collaboration and the wider community. Evaluation of the PIS-PK program in Malang City is carried out twice a year through an integrated application.
\end{abstract}

Keywords: political support; evaluation; communication; PIS-PK; sustainability

\begin{abstract}
Abstrak
Hasil capaian Program Indonesia Sehat dengan Pendekatan Keluarga (PIS-PK) belum mencapai 100 persen. Kegiatan kunjungan rumah dan intervensi terjadi ketimpangan dalam pelaksanaannya pada tingkat nasional maupun daerah. Pelaksanaan intervensi lanjutan dilakukan sebanyak 32 persen Puskesmas di Indonesia. Pelaksanaan PIS-PK di Kota Malang juga dalam periode 2017-2019 mencapai 40 persen kunjungan rumah dan belum maksimal dalam intervensi lanjutan. Penelitian ini dilakukan untuk mengetahui kapasitas keberlanjutan program PIS-PK di Kota Malang. Penelitian ini merupakan penelitian deskriptif kualitatif dengan pendekatan cross-sectional. Variabel yang diteliti dalam penelitian ini adalah dukungan politik dan tokoh masyarakat, komunikasi, dan evaluasi program PIS-PK Instrumen penelitian ini dilakukan dengan human instrumen berupa pedoman wawancara Teknik pengumpulan data pada penelitian ini dilakukan dengan wawancara terstruktur kepada informan yang terdiri dari penanggung jawab program PIS-PK. Analisis data penelitian ini dilakukan dengan cara mereduksi dan menarik kesimpulan hasil wawancara. Dukungan politik dan tokoh masyarakat dilakukan di tingkat Puskesmas dengan RT, RW, Kelurahan namun pemerintah kota tidak dukungan yang maksimal. Komunikasi yang dilakukan pada PIS-PK ini secara top to down dengan menggunakan media sosial dalam menjalin kerjasama lintas sektor maupun masyarakat luas. Evaluasi program PIS-PK di Kota Malang dilakukan selama dua kali dalam setahun melalui aplikasi yang telah terintegrasi.
\end{abstract}

Kata kunci: dukungan politik; evaluasi; komunikasi; PIS-PK; sustainabilitas

\section{Pendahuluan}

Program Indonesia Sehat Pendekatan Keluarga (PIS-PK) merupakan salah satu bentuk Nawacita ke-5 RPJMN tahun 2015-2019 sebagai upaya pemerintah pusat dan daerah dalam 
pembangunan kesehatan secara menyeluruh (Bappenas, 2014).Tujuan dari PIS-PK adalah meningkatkan derajat kesehatan masyarakat dan pengembangan keluarga yang sehat dan sejahtera (Kementerian Kesehatan RI, 2016; Kementerian Pemberdayaan Perempuan, 2009). Program ini melakukan optimalisasi fungsi keluarga sebagai unit terkecil melalui 12 indikator utama penanda status kesehatan keluarga. Pelaksanaan PIS-PK meliputi pencatatan melalui kunjungan rumah tangga dan intervensi lanjutan di fasilitas kesehatan (Kementerian Kesehatan RI, 2016).

Pelaksanaan pendataan status kesehatan keluarga melalui kunjungan rumah tangga secara nasional mengalami peningkatan selama 2017-2019 dari tahun 2017 sebanyak 24, 6\% (4.840.623 KK), tahun 2018 sebanyak 64,05 \% (25, $204.662 \mathrm{KK})$ hingga target pada tahun 2019 sebanyak 65.588.400 KK. Pada tingkat provinsi khususnya di Jawa Timur sejak tahun 2018-2019 telah mencapai 43,24\% pada jumlah kunjungan rumah tangga (Kementerian Kesehatan Republik Indonesia, 2018; Wibowo, 2019). Kondisi berbeda terjadi di Kota Malang, berdasarkan studi pendahuluan yang dilakukan pelaksanaan PIS-PK sejak tahun 2017-2019 capaian kunjungan rumah tangga sebanyak 40\% dari 16 Puskesmas yang tersebar di 5 kecamatan.

Hal berbeda terjadi pada pelaksanaan intervensi lanjutan, tercatat sebanyak 3.257 Puskesmas (32\%) di seluruh Indonesia yang memanfaatkan hasil kunjungan rumah tangga untuk dilakukan intervensi lanjutan (Kementerian Kesehatan Republik Indonesia, 2018). Kejadian serupa terjadi di Kota Malang bahwa pelaksanaan intervensi lanjutan belum maksimal yang disebabkan capaian pendataan kunjungan rumah tangga yang belum mencapai $100 \%$. Temuan ini selaras dengan penelitian terdahulu bahwa adanya ketimpangan cakupan pendataan dan pemberian intervensi pada pelaksanaan PIS-PK mulai dari awal perencanaan hingga pelaksanaan (Asri \& Budiono, 2019; Dina Lolita daulay, Ismail Efendi, 2019; Rusdianah \& Widiarini, 2019; Sari, Suryawati, Nandini, Kesehatan, \& Masyarakat, 2019). Pelaksanaan PISPK dalam periode tahun 2015-2019 yang belum maksimal menjadi catatan besar dalam pelaksanaan PIS-PK untuk tahun selanjutnya. Hal ini bila terus menerus terjadi dapat memengaruhi penggambaran status kesehatan masyarakat dan tidak terwujudnya pembangunan kesehatan yang menyeluruh.

Pendekatan keluarga yang dimaksudkan sebagai strategi keberlanjutan program PIS-PK tidak terlepas dari dukungan berbagai pihak dalam pelaksanaannya. Pengukuran kapasitas keberlanjutan program PIS-PK dapat dijadikan gambaran hasil maupun output program yang memerhatikan karakteristik program secara internal maupun eksternal (Stoll et al., 2015).Namun, keterbatasan sarana, sumber daya manusia, kesulitan input data hingga manajemen teknis pendataan menjadi hal yang muncul dalam pelaksanaan PIS-PK (Agustina \& Trisnantoro, 2019; Novianti, Sulistiyowati, Simarmata, Prasodjo, Anwar, Laelasari 2020).

Permasalahan serupa terjadi pada tingkat nasional hingga daerah yang menjadi hambatan keberlanjutan PIS-PK dalam mencapai Indonesia Sehat tahun 2025. Data-data tersebut menjadi pertimbangan bagi tiap pemerintah daerah bahkan tingkat puskesmas dalam mencapai target dan strategi untuk keberlanjutan program PIS-PK. Puskesmas menjadi salah satu instansi penting pelaksana PIS-PK. Puskesmas Dinoyo dan Puskesmas Kendalsari menjadi pelaksana aktif PIS-PK di Kota Malang sejak tahun 2017 hingga sekarang. Kegiatan pendataan dan intervensi belum mencapai target menjadi tugas tambahan pada tiap periode kerja. Oleh karena itu, diperlukan penelitian secara mendalam mengenai keberlanjutan PIS-PK khususnya 
di Kota Malang untuk menemukan titik permasalahan dan memberikan solusi guna meningkatkan derajat kesehatan masyarakat khususnya Kota Malang dengan adanya PIS-PK.

\section{Metode}

Penelitian ini merupakan penelitian deskriptif kualitatif dengan pendekatan cross sectional. Penelitian ini dilakukan di wilayah kerja Dinas Kesehatan khususnya Puskesmas Dinoyo dan Puskesmas Kendalsari. Pemilihan lokasi penelitian berdasarkan kriteria peneliti meliputi bersedia menjadi lokasi penelitian, telah melakukan tahap evaluasi awal dari Pihak Dinas Kesehatan serta menjadi pelaksana aktif PIS-PK sejak tahun 2017 hingga sekarang Metode kualitatif digunakan karena bertujuan untuk mengetahui secara mendalam mengenai keberlanjutan program PIS-PK di Kota Malang di masing masing faktor pendukung program.Teknik pengambilan data melalui wawancara terstruktur. Penelitian ini menggunakan 3 orang informan yang terdiri dari 1 orang penanggung jawab program tingkat Kota, dan 2 orang penanggung jawab tingkat Puskesmas. Instrumen penelitian yang digunakan merupakan peneliti sendiri (Human Instrument) yang didasarkan dari buku pedoman monitoring dan evaluasi PIS-PK dan sustainability assessment pada teori multidimensional Instrumen penelitian berisi pertanyaan mengenai faktor dukungan politik dan tokoh masyarakat, komunikasi dan evaluasi program yang terdiri dari 20 poin pertanyaan.

Pada penelitian ini data yang digunakan oleh peneliti adalah data primer. Data primer diperoleh dari hasil wawancara terhadap ke-3 informan mengenai pelaksanaan PIS-PK di Kota Malang. Hasil wawancara ke-3 informan disajikan dalam bentuk tabel transkrip pemetaan kualitatif untuk memudahkan dalam proses analisis data. Pemeriksaan keabsahan data dalam penelitian ini dilakukan dengan menggunakan teknik triangulasi. Teknik triangulasi yang digunakan dalam penelitian ini adalah triangulasi sumber. Triangulasi sumber adalah menggali kebenaran informasi tertentu melalui berbagai metode dan sumber perolehan data. Teknik analisis data pada penelitian ini dilakukan dengan cara menjabarkan jawaban dari pertanyaan wawancara sesuai variabel penelitian dalam tabel transkrip wawancara dan dilakukan penarikan kesimpulan dari keseluruhan hasil wawancara pada tiap variabel penelitian.

\section{Hasil dan Pembahasan}

\subsection{Hasil}

\subsubsection{Karakteristik Wilayah dan Informan}

Data dari informan didapatkan melalui wawancara mendalam kepada informan terpilih yaitu pemegang program tingkat Kota.Validitas data dilakukan dengan triangulasi kepada informan triangulasi sumber yaitu pemegang program pada tingkat Puskesmas. Berikut adalah karakteristik informan pada penelitian ini: 
Tabel 1. Karakteristik Informan Penelitian

\begin{tabular}{llllll}
\hline Informan & Umur & $\begin{array}{c}\text { Pekerjaan } \\
\text { (Jabatan) }\end{array}$ & $\begin{array}{c}\text { Pendidikan } \\
\text { Terakhir }\end{array}$ & Asal Instansi & $\begin{array}{c}\text { Status } \\
\text { Kepegawaian }\end{array}$ \\
\hline Informan 1 & 37 tahun & $\begin{array}{l}\text { Penanggung- } \\
\text { jawab Program }\end{array}$ & S1 Gizi & $\begin{array}{l}\text { Puskesmas } \\
\text { Kendalsari }\end{array}$ & Tetap \\
Informan 2 & 47 tahun & $\begin{array}{l}\text { PIS-PK } \\
\begin{array}{l}\text { Penanggung- } \\
\text { jawab Program }\end{array}\end{array}$ & D4 Gizi & Puskesmas Dinoyo & Tetap \\
Informan 3 & 57 tahun & $\begin{array}{l}\text { PIS-PK } \\
\text { Pemegang } \\
\text { program PIS- } \\
\text { PK }\end{array}$ & S1 kedokteran & $\begin{array}{l}\text { Dinas Kesehatan } \\
\text { Kota Malang }\end{array}$ & Tetap \\
\hline
\end{tabular}

Puskesmas Dinoyo dan Puskesmas Kendalsari merupakan Puskesmas terletak di Kecamatan Lowokwaru. Kedua Puskesmas ini telah terakreditasi sejak tahun 2017. Wilayah kerja Puskesmas Dinoyo meliputi kelurahan Sumbersari, Merjosari, Tlogomas, Tunggul Wulung, dan Dinoyo. Puskesmas Kendalsari memiliki wilayah kerja meliputi kelurahan Lowokwaru, Tulusrejo dan Jatimulyo. Kedua Puskesmas ini memiliki layanan rawat inap dan tersedia PONED (Pelayanan Obstetri Neonatal Dasar).

Tabel 2. Karakteristik Puskesmas Dinoyo dan Puskesmas Kendalsari

\begin{tabular}{lcc}
\hline \multicolumn{1}{c}{ Komponen } & Puskesmas Dinoyo & Puskesmas Kendalsari \\
\hline Status lembaga & BLUD & BLUD \\
Status akreditasi & Madya & Madya \\
Jenis pelayanan & Rawat inap & Rawat inap \\
Ketersediaan PONED & PONED & PONED \\
Jumlah wilayah kerja & 5 Kelurahan & 3 Kelurahan \\
Jumlah penduduk & 77.840 jiwa & 55.667 \\
\hline
\end{tabular}

\subsubsection{Dukungan Politik dan Tokoh Masyarakat}

Berdasarkan hasil wawancara ditemukan bahwa tokoh masyarakat yang berperan dalam pelaksanaan PIS-PK yaitu pihak Kelurahan, RT, RW, dan kader Posyandu. Berikut pendapat yang disampaikan oleh informan :

"Ada biasanya dibantu ketua RT, RW, pihak kelurahan"

“...RT RW nya jadi diinformasikan jadi pas survei kita nanti didampingi oleh mereka dan bisanya juga kader posyandu..."

Hal lain dijelaskan oleh informan bahwa dukungan politik dan tokoh masyarakat dalam pelaksanaan PIS-PK terbatas pada tingkat Puskesmas. Pemerintah Kota maupun Dinas Kesehatan tidak memiliki peran aktif dalam pelaksanaan PIS-PK. Salah satu informan berpendapat sebagai berikut:

“...kalo biasanya di tingkat puskesmas ya kader yang biasanya membantu menunjukkan ke rumah rumah warga kalo di tingkat kota tidak ada kerjasama lintas sektor"(Informan 3) 
Bentuk dukungan yang diberikan pada pelaksanaan PIS-PK pada tingkat Puskesmas berupa bantuan tenaga dalam kegiatan survei kunjungan rumah seperti yang dituturkan berikut:

"Oh kalo itu ada. Ya paling banyak ya berupa tenaga. Jadi tokoh masyarakat sebelum pandemi dulu juga ikut mengantar kita petugas kesehatan untuk keliling ke masyarakat. ..."

"Cuma masyarakat juga lebih dilakukan pemantauan dari pihak setempat saja"(Informan 1)

"Kalo tokoh masyarakat sebagai penggerak saja jadi kita kalo kunjungan ke masyarakat kita juga menginformasikan ke RT RW nya jadi diinformasikan jadi pas survey kita nanti didampingi oleh mereka dan bisanya juga kader posyandu..."(Informan 2)

Bentuk dukungan tambahan dari pihak internal instansi dalam keberlanjutan pelaksanaan PIS-PK pada tingkat Kota meliputi advokasi kepada pihak eksekutif atau pemerintah kota setempat, seperti yang dituturkan sebagai berikut :

"Iya ada. kami mengalokasikan lewat BOK tapi tidak bisa dipakai karena peraturannya gak boleh tapi untuk tahun 2021 ini insya Allah bisa karena kita menganut permendagri tapi ya susah nya sekarang ini kondisi pandemi" (Informan 3)

Hal yang berbeda dilakukan pada tingkat Puskesmas menyatakan tidak adanya dukungan dari pihak internal. Adanya dukungan dalam bentuk lain pada pihak internal lebih menekankan pada kegiatan penjadwalan petugas dan pengaplikasian tiap penanggungjawab program dalam pelaksanaan solusi permasalahan, sebagai berikut:

"Kalo dari puskesmas sendiri gak ada sih mbak. Kita ya ngikut apa arahan dinkes" (Informan 2)

"Kalo dukungan dari pihak puskesmas ya mungkin apa ya kayak penjadwalan. Jadi dilakukan semua petugas jadi kita ada jadwal bergiliran untuk survei dan untuk intervensi nya langsung dilakukan oleh pelaksanaan atau pemegang program" (Informan 1)

\subsubsection{Komunikasi}

Hasil wawancara ditemukan bahwa proses penyampaian informasi mengenai program PIS-PK berlangsung dari atas (Dinas Kesehatan) ke bawah (Puskesmas) hingga ke masyarakat luas. Hal berbeda ditemukan bahwa komunikasi lintas sektor tidak dilakukan pada tingkat Kota sesuai penuturan informan sebagai berikut :

“...kan sesuai SOP ini jadi tiap ada program baru kita lakukan sosialisasi ke puskesmas untuk pelatihan dan kalo puskesmas yang dilatih itu ada perwakilan 7 orang tiap puskesmas dan proporsi nya sudah pas dan itu untuk 9 puskesmas yang menjadi lokus dan sekitar 2 minggu setelahnya saya transfer ilmu untuk 7 puskesmas lainnya..."(Informan 3)

"kalo dari kami langsung ke puskesmas jadi nanti puskesmas yang berkoordinasi dengan pihak kelurahan dan lintas sektor lainnya" (Informan 3) 
Komunikasi lintas sektor pada tingkat Puskesmas melibatkan peran tokoh masyarakat seperti pihak kelurahan, RT, RW, dan Kader Posyandu dalam proses penyebaran informasi dan penyampaian kegiatan dalam PIS-PK. Hal ini dilihat dari pendapat informan berikut:

"Biasanya kami janjian dulu sama RT atau RW nya habis itu kami datang sambil didampingi mereka. biasanya juga setiap awal kita mau kunjungan kita koordinasi ke pihak kelurahan setelah itu kita sosialisasikan perkiraan jadwalnya jadi nanti kita juga lebih gampang dan kita juga minta contact person nya biar bisa lebih mudah koordinasi. dan 1 minggu sebelumnya kita kontak RT atau RW nya biar koordinasi saat di lapangan bisa mendampingi"..."biasanya lewat acara masyarakat kayak tahlilan, dasawisma, PKK jadi mereka biasanya menginformasikan juga lewat itu" (Informan 1)

"kita sampaikan ke lintas sektor biasanya ada pertemuan kader setiap bulan kita informasinya biasanya hasil atau agenda selanjutnya kita di share di grup kader dan tokoh masyarakat. kalo terus RT RW biasanya kita informasikan ke pak lurah karena kita kan ada pertemuan lintas sektor 3 bulan sekali jadi kita informasikan ke pak lurah . ya nanti itu lintas sektornya ya ada dari kelurahan kecamatan RT RW"(Informan 2)

Penerimaan positif dalam pelaksanaan PIS-PK diberikan oleh tokoh masyarakat maupun masyarakat. Pada pelaksanaan program petugas mengalami kesulitan akses pada beberapa lingkungan dengan adanya kegiatan PIS-PK seperti berikut:

"ya kalo yang di kampung kampung gitu sih enak ya tapi susah nya ya yang di perumahan elit itu kan tetap harus di data kadang malah keberatan dengan kedatangannya kita. biasanya kita sudah nunggu lama kadang yang keluar anjingnya wkwk kadang ya cuma pembantunya saja jadi ya kesulitannya ya di waktu itu kan soalnya kita survey nya pas jam kerja jadi ya ada yang masih kerja gitu" (Informan 2)

Penggunaan media sosial berupa grup whatsapp menjadi media yang sering digunakan dalam proses penyebarluasan informasi dan membangun komunikasi aktif dengan tokoh masyarakat maupun masyarakat. Sesuai penuturan berikut:

“...teknologi jadi setelah sosialisasi atau ada info apa kita ngeshare ke kader atau tokoh masyarakat terus di share lagi ke grup RT atau RW gitu biasanya. jadi informasinya nyampai..." (Informan 2)

“... kita juga minta contact person nya biar bisa lebih mudah koordinasi. dan 1 minggu sebelumnya kita kontak RT atau RW nya biar koordinasi saat di lapangan bisa mendampingi" (Informan 1)

\subsubsection{Evaluasi Program}

Hasil wawancara ditemukan bahwa capaian pelaksanaan PIS-PK di Kota Malang belum mencapai $100 \%$ dalam kegiatan kunjungan rumah maupun intervensi dalam periode 20172020. Hal ini sesuai dengan pendapat informan sebagai berikut:

“...kami belum 100\%. jadi kalo itu kan kami menghitungnya per kelurahan jadi missal puskesmas arjowinangun ada 4 kelurahan yang total coverage itu 2 kelurahan tapi memang beberapa puskesmas sudah ada yang 100\%" (Informan 3) 
"nah ya itu mbak gak mungkin kalo sampe $100 \%$ itu menurut saya di mana mana itu gak mungkin. kalo disini ya semisal $70 \%$ ya sudah kita anggap mewakili keseluruhan wilayah kelurahan..."(Informan 2)

Pelaksanaan PIS-PK di Kota Malang memiliki beberapa kendala dalam pelaksanaannya. Keadaan pandemi COVID-19, pembiayaan operasional program, keterampilan sumber daya manusia hingga dukungan pihak luar dalam penyebarluasan informasi program merupakan beberapa kendala yang muncul saat pelaksanaan PIS-PK. Pendapat ini diutarakan sebagai berikut:

"kalo saya sendiri ya kendala dana sebetulnya temen temen puskesmas itu kan tidak hanya kunjungan untuk pis pk dan biasanya bekerja diluar jam kerja dan jujur saja tidak ada biaya tambahan untuk teman teman ... dan selanjutnya ya setiap orang menjadi atau memegang banyak program 1 orang .... dan ketiga ya suasana pandemi ini, kalo jujur ya kan sudah banyak kasus positif jadi kami sendiri juga bingung kalo mau turun ke lapangan tidak dilakukan jadi yang bisa dilakukan hanya intervensi untuk data lama yang sudah di verifikasi..."(Informan 3)

“...memang PIS-PK ini menurut saya ini masih kurang ada gebyar nasional nya gitu lo sehingga gak ada kewajiban untuk semua orang tau atau ikut ya Karena kurang digebyarkan baik tingkat nasional apalagi tingkat kota jadi yang tau Cuma dinkes sama puskesmas"(Informan 3)

“...ya kendalanya kita kekurangan SDM juga ya mbak proporsinya juga sudah gak seimbang dan kita juga kebanyakan program jadi ya itu sih. soalnya kan semua program itu entry nya masing masing lagi jadi tiap program punya sistem masing masing.." (Informan 2)

Mekanisme evaluasi program pelaksanaan PIS-PK telah terintegrasi melalui aplikasi Keluarga Sehat buatan Kementerian Kesehatan Republik Indonesia. Evaluasi dapat dilihat melalui perkembangan pengisian data pelaksanaan PIS-PK Berikut adalah pendapat yang dijabarkan informan :

"Kita ada pelaporan setiap bulan jadi kita laporkan perkembangan nya mulai dari kunjungan rumah dan intervensi setiap bulan lewat aplikasi PIS-PK" (Informan 1)

"kalo evaluasi biasanya setelah kunjungan rumah kita evaluasi langsung kalo dari dinkes itu biasanya ada evaluasi tiap 1 tahun 2 kali biasanya tapi ya lupa wkwk sepertinya 6 bulanan. ya by data yg kita input ..."(Informan 2)

Tindak lanjut hasil evaluasi program PIS-PK hanya dilakukan pada tingkat Puskesmas berupa penyebarluasan informasi dan solusi program dengan bantuan tokoh masyarakat setempat. Rekomendasi usulan program maupun kebijakan tingkat Kota melalui kerjasama lintas sektor tidak dilaksanakan seperti yang dituturkan berikut :

“...tapi kalo di dinkes belum ada soalnya kita juga banyak program tapi sebetulnya ini kan program lama tapi ada perubahan sedikit jadi untuk ke dinas dinas lain itu masih belum."(Informan 3)

"Jadi kan kita petugas kesehatan sudah mengedukasi dan setelah diinformasikan ke RT RW atau kelurahan setempat nanti kita juga mengusulkan program jadi nanti sesuai juga masalah yang teratasi. masyarakat juga saat ada program ikut serta memantau, misalnya kan kita sudah bikin jamban sehat nanti yang memonitoring 
itu ya juga dari mereka sendiri kalo dari petugas kesehatan hanya 1 bulan sekali" (Informan 1)

"iya kita informasikan, biasanya lewat pertemuan lintas sektor itu kan kita ada musrembang itu ya disitu"..."jadi kita ya hanya menunaikan tugas saat survey itu tadi dan untuk intervensinya kami biasanya langsung berikan datanya ke pemegang program masing masing biar di intervensi sendiri sesuai permasalahan. kalo ditindaklanjuti itu sudah itu biasanya langsung ditindak lanjuti," (Informan 2)

\subsection{Pembahasan}

\subsubsection{Dukungan Politik dan Tokoh Masyarakat}

Hasil penelitian ditemukan bahwa pelaksanaan PIS-PK tingkat Kota di Kota Malang belum ada dukungan lintas sektor dari pemerintah daerah maupun dinas lainnya. Hal ini berbeda dengan Pedoman Pelaksanaan PIS-PK bahwa dalam pelaksanaan PIS-PK perlu melibatkan lintas sektor maupun pemerintah daerah setempat. Pelaksanaan PIS-PK pada tingkat Puskesmas di Kota Malang melibatkan pihak lintas sektor meliputi pihak kelurahan, RW, RT maupun Kader Posyandu. Hal ini sesuai Peraturan Menteri Kesehatan Nomor 39 Tahun 2016 tentang Program PIS-PK bahwa perlu dilakukannya koordinasi lintas sektor dalam pelaksanaan program PIS-PK pada tingkat provinsi, tingkat kota maupun Puskesmas. Selaras dengan temuan Sri Budi Utami (2018) bahwa kerjasama lintas sektor mulai dari tingkat RT hingga pemerintah daerah dapat meningkatkan jumlah intervensi sekaligus sebagai pelaksana, pendukung maupun pengawas program (Utami, 2019). Bentuk dukungan yang diberikan dalam pelaksanaan PIS-PK di Kota Malang sebagian besar berupa tenaga dalam proses pendataan kunjungan rumah. Sesuai dengan Permenkes No 39 Tahun 2016 dalam tahap persiapan pelaksanaan PIS-PK (P1), bahwa perlu diadakan sosialisasi internal kepada petugas puskesmas yang belum dilatih maupun eksternal yang melibatkan lintas sektor di wilayah kerja puskesmas. Lintas sektor juga berperan dalam memberikan listing nama KK, mengkondisikan warganya sehingga kunjungan rumah ulang tidak sampai berkali-kali dilakukan (Suratri, 2019).

Peraturan yang digunakan dalam pelaksanaan PIS-PK di Kota Malang meliputi Permenkes Nomor 39 Tahun 2016 tentang Pedoman Penyelenggaraan Program Indonesia Sehat dengan Pendekatan Keluarga, SK Kadinkes dan SK Kepala Puskesmas.Terjemahan atas kebijakan tersebut hanya diinformasikan ke Puskesmas untuk pembentukan Tim pelaksana PIS-PK selanjutnya. Hal berbeda di temukan bahwa Pemerintah daerah tidak diberikan sosialisasi mengenai program dalam pelaksanaan PIS-PK di Kota Malang namun pihak Dinkes melakukan advokasi dalam proses pelaksanaan. SOP dan panduan pelaksanaan program dibuat berdasarkan peraturan yang telah ditentukan. Penggunaan SOP, SK maupun pedoman penyelenggaran menjadi upaya peningkatan mutu suatu program dan memperkuat dasar kebijakan pelaksanaan program (Fauzan, Chotimah, \& Hidana, 2019). Hal ini selaras dengan penelitian Andalia,dkk (2020) adanya hubungan secara signifikan antara pengetahuan, sikap, komunikasi dan birokrasi dengan implementasi kebijakan PIS-PK (Andalia, Aritonang, \& Sitorus, 2020). 


\subsubsection{Komunikasi}

Hasil penelitian ditemukan bahwa proses penyampaian informasi mengenai program PIS-PK adalah dari Dinas Kesehatan ke Puskesmas terkait dalam bentuk sosialisasi maupun pelatihan bagi tim pelaksana program. Penyampaian informasi lintas sektor juga dilakukan dalam pelaksanaan PIS-PK. Hal ini sesuai dengan Permenkes No. 39 Tahun 2016 bahwa perencanaan pelaksanaan program dilakukan sosialisasi internal maupun eksternal .Hal berbeda ditemukan oleh Arifin Arifni, dkk (2021) bahwa tidak ada hubungan antara pengetahuan masyarakat dengan pelaksanaan PIS-PK karena informasi yang disampaikan ke masyarakat belum sampai secara langsung oleh masyarakat (Arifni, Husna, \& Kamal, 2021). Penyampaian informasi diberikan kepada perwakilan tokoh masyarakat melalui sosialisasi maupun melalui kegiatan masyarakat lainnya. Banyaknya pihak lintas sektor lain dalam penyampaian informasi mengenai PIS-PK menjadi kesulitan dalam proses terjadinya komunikasi dalam program (Roeslie \& Bachtiar, 2018). Tanggapan masyarakat dalam pelaksanaan PIS-PK di Kota Malang sebagian besar sudah positif hanya beberapa wilayah yang menolak dalam proses kunjungan rumah tangga. Hal ini sesuai dengan penelitian Ifon Driposwana Putra dan UlfaHasana (2019) bahwa sebanyak 66\% responden memberikan respon positif dengan adanya kunjungan rumah pada program PIS-PK. Pemberian edukasi dan sosialisasi memang peranan penting atau mempengaruhi seseorang dalam menerapkan PISPK untuk menjadikan seseorang atau keluarga menjadi keluarga sehat (Putra \& Hasana, 2020).

Penggunaan media informasi dalam penyelenggaraan PIS-PK bisanya berupa flyer, booklet maupun poster dalam proses penyampaiannya melalui sosialisasi. Media yang sering digunakan adalah berupa Pinkesga belum dimaksimalkan dalam pelaksanaannya, petugas bersifat memberikan secara garis besar tanpa ada pengetahuan mendalam sehingga masyarakat tidak paham betul dengan materi yang diberikan (Suratri, 2019). Komunikasi antar lintas sektor juga menjadi hal yang dilakukan dalam penyampaian informasi masyarakat berupa sosialisasi dalam pertemuan lokakarya mini, media sosial, bidan desa dan pertemuan desa dengan melibatkan para aparat desa, RT/RW dan kader Posyandu. Hal ini dilakukan dengan tujuan mengurangi penolakan saat adanya kunjungan rumah tangga (Sulistiowati, Yunianto, \& Idaiani, 2020).

\subsubsection{Evaluasi Program}

Hasil penelitian ditemukan bahwa hasil capaian dari kunjungan rumah di Kota Malang belum mencapai $100 \%$. Hal ini tidak memenuhi target capaian program PIS-PK tingkat Kota maupun nasional sesuai yang tertulis pada renstra 2015-2019 (Bappenas, 2014). Hal ini ditambah dengan Permenkes Nomor 39 Tahun 2016 diketahui bahwa pendataan keluarga harus dilaksanakan secara pada semua keluarga di wilayah kerja Puskesmas (total coverage), apabila terdapat keterbatasan sumber daya baik sumber daya manusia maupun dana, maka pendataan dapat dilakukan pada semua keluarga di 1 desa terlebih dahulu kemudian melanjutkan ke desa selanjutnya (Kementerian Kesehatan RI, 2016). Permasalahan yang dihadapi dalam pelaksanaan PIS-PK di Kota Malang salah satunya adalah permasalahan pembiayaan operasional yang belum tersedia. Keterbatasan dana berakibat pada keterbatasan semua komponen yang berkaitan dengan kelancaran keseluruhan kegiatan (Laelasari, Anwar, \& Soerachman, 2017). Anggaran dana BOK sesuai dengan Permenkes Nomor 19 Tahun 2017 menjelaskan bahwa adanya transportasi tenaga pendataan dan dana BLUD digunakan untuk 
pengadaan alat seperti tensimeter dan stetoskop(Kementerian Kesehatan Republik Indonesia, 2017).

Permasalahan sumber daya manusia belum memadai juga menjadi permasalahan yang dialami dalam pelaksanaan PIS-PK di Kota Malang. Penambahan beban kerja terjadi karena ketersediaan tenaga kurang dibandingkan tugas pokok di Puskesmas sehingga proses pendataan tidak maksimal (Virdasari \& Arso, 2018). Sejalan dengan hasil penelitian Markus (2018) bahwa beban tugas sehari hari sudah menyita tenaga dan waktu sehingga sulit apabila ditambahkan dengan tugas melaksanakan PIS-PK (Agni, 2018). Pelaksanaan pendataan PISPK Kota Malang dilakukan oleh tenaga kesehatan secara langsung. Hal tersebut tidak sesuai dengan Permenkes Nomor 39 Tahun 2016 bahwa puskesmas dapat bekerjasama dengan institusi lain atau merekrut tenaga untuk pengumpulan data. Hal ini juga ditemukan dalam penelitian yang dilakukan oleh Laelasari et al. (2017) bahwa yang menjadi kendala dalam pelaksanaan pendataan PIS-PK di puskesmas adalah belum ada peningkatan pengetahuan sumber daya terutama mengenai IT dan analisis data pendataan PIS-PK sehingga mengakibatkan terhambatnya data dan solusi hasil yang sesuai (Sugiharti, Mujiati, Masitoh, \& Laelasari, 2019).

Proses penyebarluasan informasi lintas sektor pada tingkat Kota di Kota Malang juga belum optimal. Berdasarkan studi dari Pujosiswanto., dkk (2020) menemukan bahwa tantangan operasional program dimana faktor komunikasi yang tidak memadai dan panduan layanan yang tidak jelas berkontribusi terhadap ketidakefektifan dalam belanja anggaran dan penyediaan layanan (Pujosiswanto, Palutturi, \& Ishak 2020). Evaluasi program PIS-PK pada tingkat Puskesmas maupun Kota dilakukan melalui aplikasi yang telah terintegrasi. Dilakukan pelaporan setiap 6 bulan sekali melalui aplikasi oleh Puskesmas yang dipantau secara langsung oleh Dinas Kesehatan Kota Malang. Hal ini sesuai dengan Pedoman Monev Pelaksanaan PIS-PK bahwa monitoring dan evaluasi PIS-PK dilakukan pada tiap tingkat meliputi Puskesmas tingkat Kota dan tingkat Provinsi. Monitoring meliputi proses input data, analisis data, verifikasi data dan tindak lanjut oleh penanggung jawab bina wilayah.Pelaksana PIS PK juga menyampaikan, kegiatan monitoring dan evaluasi belum terlaksana secara optimal karena keterbatasan SDM. Padahal semua pihak yang terlibat pertanggung jawab terhadap pelaksanaan PIS-PK. Sehingga evaluasi yang dilakukan harus berjenjang sesuai dengan tugas dan fungsi masing-masing level penanggung jawab (Kementerian Kesehatan RI, 2017). Hasil penelitian menyatakan tindak lanjut hasil evaluasi program PIS-PK di Kota Malang berupa penyebarluasan informasi dan solusi program pada tingkat Puskesmas dan pengusulan rekomendasi usulan program maupun kebijakan tingkat Kota kepada Pemerintah Daerah namun tidak dilakukan melalui kerjasama lintas sektor. Tindak lanjut yang dilakukan berbeda pada hasil penelitian Rachman (2019) sebesar 30,9\% keluarga dilakukan kunjungan lanjutan dari hasil kunjungan rumah tangga awal dan menganalisis hasil intervensi awal (Rachma et al., 2019). Binwil akan menyampaikan hasil analisis dan rekomendasi tindak lanjut kepada pemerintah daerah Provinsi atau Kota melalui surat ataupun pertemuan untuk dapat ditindaklanjuti secara berjenjang hingga ke puskesmas sesuai tupoksi dan kewenangan masing masing (Kementerian Kesehatan RI, 2017).

\section{Simpulan}

Keberlanjutan Program Indonesia Sehat dengan Pendekatan Keluarga (PIS-PK) melalui dimensi dukungan politik, komunikasi dan evaluasi program layak dilanjutkan dengan beberapa catatan penting. Catatan penting yang diperhatikan dalam pelaksanaan PIS-PK 
selanjutnya adalah kejelasan kedudukan hukum dan pelaksana program PIS-PK pada tiap tingkat sehingga petugas dalam melaksanakan program tidak bingung, penyediaan sumber daya manusia dalam proses pelaksanaan program dalam kegiatan pendataan hingga input data serta peningkatan kerjasama lintas sektor pada tiap tingkat sehingga aplikasi solusi permasalahan tepat sasaran dan berkelanjutan.

\section{Daftar Rujukan}

Agni, M. G. K. (2018). Kesiapan Daerah Istimewa Yogyakarta Dalam Penerapan Program Indonesia Sehat Dengan Pendekatan Keluarga. Jurnal Formil, 3(1), 43-49.

Agustina, S.C., Trisnantoro, L., dan H. (2019). Analisis Program Indonesia Sehat Dengan Pendekatan Keluarga ( Pis-Pk) Dalam Capaian Awal Pelaksanaan Latar Belakang Berdasarkan Undang-Undang 36 Tahun 2009 tentang kesehatan, diperlukan upaya pembangunan kesehatan untuk meningkatkan kualitas sumber daya. PROSIDING HEFA 4th 2019, P ISSN 258, 44-51.

Andalia, R. Y., Aritonang, E. Y., \& Sitorus, F. E. (2020). Analisis Faktor Implementasi Program PIS-PK di Puskesmas Gading Padang Lawas Tahun 2020. Jurnal Inovasi Kesehatan Masyarakat, 2(1), 85-93.

Arifni, A., Husna, Y., \& Kamal, K. (2021). Pengaruh pengetahuan dan sikap masyarakat terhadap pelaksanaan pis-pk di puskesmas. 6(1), 32-38.

Asri, A. C., \& Budiono, I. (2019). Pelaksanaan Program Indonesia Sehat dengan Pendekatan Keluarga di Puskesmas. Higea Journal of Public Health, 3(4), 556-567.

Bappenas. (2014). Rencana Pembangunan Jangka Menengah (RPJMN) tahun 2015-2019: Agenda Pembangunan Nasional. 1, 311.

Dina Lolita daulay, Ismail Efendi, N. (2019). Evaluasi Pelaksanaan Program Indonesia Sehat dengan Pendekatan Keluarga Sehat (PIS-PK) di Puskesmas Bestari Kota Medan. 2(2).

Eri Virdasari, Septo Pawelas Arso, E. Y. F. (2018). Analisis kegiatan pendataan keluarga program indonesia sehat dengan pendekatan keluarga di puskesmas kota semarang (Studi Kasus pada Puskesmas Mijen). 6(2), 52-65.

Fauzan, A., Chotimah, I., \& Hidana, R. (2019). Implementasi Program Indonesia Sehat Dengan Pendekatan Keluarga (Pis-Pk) Di Puskesmas Mulyaharja Kota Bogor Tahun 2018. Promotor, 2(3), 172. https://doi.org/10.32832/pro.v2i3.1934

Kementerian Kesehatan Republik Indonesia. (2017). Peraturan menteri kesehatan republik indonesia nomor 19 tahun 2017 tentang pedoman pendanaan program indonesia sehat dengan pendekatan keluarga. 1-27.

Kementerian Kesehatan Republik Indonesia. (2018). Perkembangan PISPK (Program Indonesia Sehat Dengan Pendekatan Keluarga) 2018.

Kementerian Kesehatan RI. (2016). Pedoman Umum Program Indonesia Sehat dengan Pendekatan Keluarga.

Kementerian Kesehatan RI. (2017). Buku Monitoring dan Evaluasi PIS-PK. Kemenkes RI, Vol. 1, pp. 1-85.

Kementerian Pemberdayaan Perempuan. (2009). UU No 52 tahun 2009 tentang Pembangunan Keluarga.

Laelasari, E., Anwar, A., \& Soerachman, R. (2017). Evaluasi kesiapan pelaksanaan program indonesia sehat dengan pendekatan keluarga Evaluation of Readiness in Implementation of Program Indonesia Sehat Dengan Pendekatan Keluarga. 57-72.

Novianti, Ning Sulistiyowati, Oster Suriani Simarmata, Rachmalina S Prasodjo, Athena Anwar, Eva Laelasari1, J. I. (2020). Evaluasi Pelaksanaan Pis-Pk Di Puskesmas Kabupaten Labuan Batu, Provinsi Sumatera Utara Dan Kota Semarang, Provinsi Jawa Tengah. Jurnal Ekologi Kesehatan, 19(1), 59-75. https://doi.org/10.22435/jek.v19i1.2633

Pujosiswanto, K. H., Palutturi, S., \& Ishak, H. (2020). Faktor-Faktor Yang Mempengaruhi Implementasi Program Indonesia Sehat Dengan Pendekatan Keluarga ( Pis-Pk) Di Puskesmas Kabupaten Polewali Mandar Factors That Affect the Implementation of Healthy Indonesia Program Through Family Approach ( PisPk ) in Hea. Jurnal Kesehatan Masyarakat Maritim, 3(1), 123-135.

Putra, I. D., \& Hasana, U. (2020). Analisis Hubungan Sikap dan Pengetahuan Keluarga dengan Penerapan Program Indonesia Sehat dengan Pendekatan Keluarga. Jurnal Endurance, 5(1), 13. https://doi.org/10.22216/jen.v5i1.4282

Rachma, N., Widiyastuti, R. H., Andriany, M., Nurrahima, A., Hartati, E., Dewi, N. S., ... Diponegoro, U. (2019). 
Rangka program indonesia sehat dengan pendekatan Pendahuluan Program Indonesia Sehat merupakan program utama Pembangunan Kesehatan, dan dengan Rencana Pembangunan Jangka Indonesia Sehat dengan pendekatan keluarga . perluasan dari upaya Perawatan Kesehata. 3(3), 209-220.

Roeslie, E., \& Bachtiar, A. (2018). Analisis Persiapan Implementasi Program Indonesia Sehat dengan Pendekatan Keluarga (indikator 8: kesehatan jiwa) di Kota Depok Tahun 2018. Jurnal Kebijakan Kesehatan Indonesia : JKKI, 7(02), 64-73.

Rusdianah, E., \& Widiarini, R. (2019). Evaluasi program indonesia sehat dengan pendekatan keluarga (pis-pk): studi kasus di tingkat puskesmas. 8(04), 175-183.

Sari, N. R., Suryawati, C., Nandini, N., Kesehatan, K., \& Masyarakat, F. K. (2019). Evaluasi pelaksanaan program indonesia sehat dengan pendekatan keluarga (pis-pk) pada indikator tb paru di kabupaten pati (Studi Kasus pada Puskesmas Tayu II). 7, 532-541.

Stoll, S., Janevic, M., Lara, M., Ramos-Valencia, G., Stephens, T. B., Persky, V., ... Malveaux, F. (2015). A mixedmethod application of the program sustainability assessment tool to evaluate the sustainability of 4 pediatric asthma care coordination programs. Preventing Chronic Disease, 12(12), 1-10. https://doi.org/10.5888/pcd12.150133

Sugiharti, S., Mujiati, M., Masitoh, S., \& Laelasari, E. (2019). Gambaran Ketersediaan Sumber Daya Manusia dan Prasarana Puskesmas dalam Pelaksanaan Program Indonesia Sehat dengan Pendekatan Keluarga (PISPK): Analisis Data Risnakes 2017. Jurnal Penelitian Dan Pengembangan Pelayanan Kesehatan, 3(1), 3139. https://doi.org/10.22435/jpppk.v3i1.1883

Sulistiowati, E., Yunianto, A., \& Idaiani, S. (2020). Pengelolaan dan pemanfaatan data program indonesia sehat dengan pendekatan keluarga ( pispk) di puskesmas Data Management and Utilization of Healthy Indonesia Program with Family Approach at Health Centers.

Suratri, M. A. L. (2019). Pengetahuan Masyarakat dan Pelaksanaan Wawancara Program Indonesia Sehat dengan Pendekatan Keluarga (PIS-PK) di Beberapa Puskesmas di Indonesia. Jurnal Penelitian Dan Pengembangan Pelayanan Kesehatan, 3(1), 1-8. https://doi.org/10.22435/jpppk.v3i1.1867

Utami, S. R. I. B. (2019). Inovasi Kampung Rasa Sebagai Intervensi PIS-PK di Puskesmas Semanggang Kabupaten Kotawaringin Barat. 16(2), 2019.

Wibowo, B. (2019). Progress Implementasi PIS-PK. 22. 